International Journal of Bone and Rheumatology Research (IJBRR)

ISSN 2470-4520

\title{
Serum Cartilage Oligomeric Matrix Protein: Tool for early diagnosis and grading of severity of primary knee osteoarthritis.
}

Research Article

Sudhir Singh ${ }^{1}$, Utkarsh Shahi ${ }^{2}$, Dharmendra Kumar ${ }^{3}$, Neha Tiwari Shahi ${ }^{4}$

${ }^{1}$ Department of Orthopaedics, Era's Lucknow medical college and hospital, Lucknow, India.

${ }^{2} 3$ rd Junior resident of M.S. (Ortho.), Department of Orthopaedics, Era’s Lucknow medical college and hospital, Lucknow, India.

${ }^{3}$ Assistant Professor M.S.(Ortho.), Department of Orthopaedics, Era’s Lucknow medical college and hospital, Lucknow, India.

${ }^{4}$ Senior resident department of Microbiology, Sanjay Gandhi Post Graduate Institute of Medical Sciences, Lucknow, India.

\begin{abstract}
Context: With increasing elderly population there is increasing prevalence of primary degenerative knee osteoarthritis (KOA), but specific and sensitive tests to diagnose and ascertain the severity of such ailments are lacking. Bone and cartilage biomarkers, like serum Cartilage Oligomeric Matrix Protein (sCOMP) level show changes much before than clinical or radiological changes. So far it has not been used in clinical practice as the diagnostic range of serum COMP levels have not been defined.
\end{abstract}

Aims: The aim of present study was to assess the efficacy of sCOMP levels in diagnosis of different grades of severity of primary knee osteoarthritis.

Settings and design: A hospital based prospective case control study recruiting 100 cases and 50 controls.

Methods and material: All subjects were examined clinically and further evaluated by plain radiography and serum COMP values were estimated by enzyme linked immune-sorbent assay (ELISA). Multiple statistical tools were used to analyse the results.

Results: The difference between sCOMP values among cases and controls was statistically significant $(\mathrm{t}=21.774 ; \mathrm{p}<0.001)$. The mean sCOMP also shows a gradual increase with increase in severity of knee osteoarthritis. [F=38.940; $<<0.001$ (ANO$\mathrm{VA})$.

Conclusions: The serum COMP levels can be used to diagnose normal and diseased individual and also assess different grades of severity of knee osteoarthritis. We suggest cut off levels of sCOMP of 652.5 nano gram/deci litre (ng/dl) between normal and diseased individual, of $801.5 \mathrm{ng} / \mathrm{dl}$ between mild and moderate grade of osteoarthritis, and of $1100.5 \mathrm{ng} / \mathrm{dl} \mathrm{be}-$ tween moderate and severe grade of knee Osteoarthritis (KOA).

Keywords: Biomarkers, Osteoarthritis, sCOMP, ELISA, KOA

\section{*Corresponding Author}

Prof. Sudhir Singh,M.S.(Ortho),

Head - Department of Orthopaedics,

Era's Lucknow Medical College and Hospital,

Sarfarazganj, Hardoi Road, Lucknow - 226003. UP, INDIA

Phone: +91 8799544905

E-mail: susi59@live.in

Received: July 23, 2014

Accepted: August 20, 2014

Published: August 23, 2014

Citation:Sudhir Singh, Utkarsh Shahi, Dharmendra Kumar, Neha Tiwari Shahi (2014) Serum Cartilage Oligomeric Matrix Protein: Tool for early diagnosis and grading of severity of primary knee osteoarthritis. 1(1). 1-7. doi: http://dx.doi.org/10.19070/2470-4520140001

Copyright: Sudhir Singh,M.S.(Ortho) (C) 2014. This is an open-access article distributed under the terms of the Creative Commons Attribution License, which permits unrestricted use, distribution and reproduction in any medium, provided the original author and source are credited.

\section{Introduction}

With increasing elderly population we are seeing increasing numbers of persons affected with primary degenerative arthritis [1]. Among all the patients of osteoarthritis in India, it is the knee joint which is mostly involved, followed by hand and hip [2]. Most patients with arthritis are identified relatively late in the disease process. By this time considerable damage has already taken place in joint [3-5].The main goal of any diagnostic evaluation is to demonstrate the presence of disease unequivocally, or else to rule it out. A precise diagnosis enables precise treatment. The major elements of the diagnosis of knee osteoarthritis are the history, physical examination, radiographic studies. But unfortunately, none of the diagnostic elements can detect the osteoarthritis in preclinical or subclinical stage of the disease. The purpose of this study is to find solution to the problem of a) how to diagnose the disease in pre and subclinical stage and b) to correlate the disease severity of knee osteoarthritis with the Serum levels of Cartilage Oligomeric Matrix Protein (COMP). Literature search revealed that no study has been done to define of serum COMP 
level cutoff vis-a-vis grade of severity of KOA for Indian population so far.

\section{Subjects and method}

\section{Study population}

One hundred and fifty subjects (100 cases and 50 controls) were selected as per the American College of Rheumatology Clinical Classification Criteria for Osteoarthritis of the knee [6].

The sample size was calculated with prevalence based formula: $\mathrm{N}=4 \mathrm{pq} / \mathrm{L}[2]$, where, $\mathrm{n}=$ sample size, $\mathrm{p}=$ prevalence, $\mathrm{q}=100$ - p, L = Allowable error (20\% of prevalence), Power $=80 \%$ and Significance level $=5 \%$.

Cases were men and non-pregnant women, above 40 years with primary OA of knees with any three or more of the following: 1) Early morning joint stiffness, 2) Creaking/ cracking of joints after movement, 3) Bony tenderness and/or swelling around knee, 4) Bony enlargement of joints, 5) No palpable warmth of Synovium, 6) Pain that is worst after use, 7) Stiffness after period of rest and 8) Loss or restriction of joint mobility. Cases were excluded from the study if they had 1) secondary arthritis of knee joint, 2) rheumatoid arthritis, 3) taken treatment for osteoarthritis, 4) clinically active renal, hepatic or peptic ulcer disease 5) other painful or disabling conditions affecting the knee and 6) participating in any athletic activity. Controls were men and women of above 40 years with no evidence of any arthritic involvement of any joint. Exclusion criteria for controls were same as for cases. The recruited cases and controls were explained the purpose and relevance of study. Those willing to volunteer were included in the study after informed and written consent. The project was approved by the institutions ethical committee.

\section{Methodology}

Both, cases and controls were subjected to detailed history taking and physical examination. They were subjected to weight bearing antero-posterior knee radiographs. Before drawing blood samples all subjects were made to rest for half an hour in seated position to avoid the effect of activity on sCOMP levels. All the samples were drawn in late mid-day (12 noon to $4 \mathrm{pm}$ ) to avoid diurnal variations in sCOMP levels. $5 \mathrm{ml}$ whole venous blood sample of the recruited cases and controls were drawn in syringe and collected in plain vial taking all aseptic precautions. Samples were sent to Immunology laboratory in Department of Microbiology, for estimation of serum COMP levels by ELISA test (RD194080200 Human cartilage oligomeric matrix protein ELISA: BiovendorLaboratini medicina a.s.) [7]. Blood was centrifuged and serum was separated and stored in small capped vials for long term use at $-20^{\circ} \mathrm{C}$ until tested.

The severity of osteoarthritis was graded on plain radiographs by K-L grading (0-IV). The subjects were graded as normal with grade 0 , mild $\mathrm{OA}$ with grade 1 , moderate $\mathrm{OA}$ grade 2-3 and of severe $\mathrm{OA}$ with grade 4.

\section{Statistical Analysis}

Data was collected and statistically analysed with the help of Student's Paired t-test, multiple regression analysis, Analysis of variance (ANOVA) and Receiver - Operator Curve (ROC). The Receiver- operating characteristic (ROC) was used to evaluate the predictability of serum COMP levels for the presence of OA and results were calculated using Regression multivariate analysis to verify the diagnostic yield of combined measurements. The validity of multiple cutoff points to identify the valid cut-off points was assessed using sensitivity, specificity, positive predictive value (PPV), negative predictive value (NPV) and accuracy for cutoff points. $\mathrm{P}$ value $<0.05$ was considered statistically significant.

\section{Results}

\section{Study subject characteristics}

There were no gender bias in sampling in cases and controls. The age in control group (mean age 54.68 years) was significantly lower than case group (58.93 years) (Table 1). The BMI of the control group $\left(23.07 \pm 2.9 \mathrm{~kg} / \mathrm{m}^{2}\right)$ was slightly lower than in cases $\left(24.07 \pm 3.1 \mathrm{~kg} / \mathrm{m}^{2}\right)$ group but the difference was not statistically significant (Table 1).

\section{Diagnostic Study}

The serum COMP value in male controls ranges between 360 - $596 \mathrm{ng} / \mathrm{dl}$ with a mean value of $489.8( \pm 58.2) \mathrm{ng} / \mathrm{dl}$ and in female controls it ranges between 313 - $614 \mathrm{ng} / \mathrm{dl}$ with a mean value of $464.24( \pm 59.56) \mathrm{ng} / \mathrm{dl}$. The serum COMP value in overall controls ranges between $313-614 \mathrm{ng} / \mathrm{dl}$ with a mean value of $477.02( \pm 60.87) \mathrm{ng} / \mathrm{dl}$. In male controls mean serum COMP is higher than that in female controls.

The serum COMP value in male cases (mean age 58.14 years) ranges between $711-1408 \mathrm{ng} / \mathrm{dl}$ with a mean value of 960.6 ( \pm $148.08) \mathrm{ng} / \mathrm{dl}$ and in female cases (mean age 59.72 years) it ranges between $691-1434 \mathrm{ng} / \mathrm{dl}$ with a mean value of $967.76( \pm 154.29)$ $\mathrm{ng} / \mathrm{dl}$. The serum COMP value in overall cases ranges between $691-1434 \mathrm{ng} / \mathrm{dl}$ with a mean value of 964.18 ( \pm 152.02) ng/dl. Unlike controls, in cases, mean serum COMP in females is a fraction higher than those in males.

In our study the serum COMP value steadily increases with age in cases as well as controls (Fig 1). Comparing the Serum COMP values among case and controls we found a statistically significant difference $(\mathrm{t}=21.774 ; \mathrm{p}<0.001)$ (Table 1).

\section{Severity Study}

Among cases, there are $12 \%$ mild, $80 \%$ moderate and $8 \%$ severe osteoarthritis cases. The serum COMP value in mild cases ranges between $691-967 \mathrm{ng} / \mathrm{dl}$ with a mean value of $766.58( \pm 70.62)$ $\mathrm{ng} / \mathrm{dl}$. The serum COMP value in moderate cases ranges between $698-1127 \mathrm{ng} / \mathrm{dl}$ with a mean value of $967.61( \pm 118.32) \mathrm{ng} / \mathrm{dl}$. The serum COMP value in severe cases ranges between 1108 $1434 \mathrm{ng} / \mathrm{dl}$ with a mean value of $1226.25( \pm 124.29) \mathrm{ng} / \mathrm{dl}$. The mean serum COMP shows a gradual increase with increase in severity of knee osteoarthritis. [ $\mathrm{F}=38.940 ; \mathrm{p}<0.001$ (ANOVA)] (Table 2).

Receiver-Operator Curve analysis of serum COMP levels gave the cut-off values of $652.5 \mathrm{ng} / \mathrm{dl}$ to differentiate between normal and diseased cases (Table 3), of $801.5 \mathrm{ng} / \mathrm{dl}$ between mild cases from moderate cases (Table $4 \mathrm{a}$ ) and of $1100.5 \mathrm{ng} / \mathrm{dl}$ between moderate and severe case (Table 4b).

Evaluation of regressed cut-off value of $<652.5 \mathrm{ng} / \mathrm{dl}$ to differentiate between normal and diseased individuals showed very 
high sensitivity and specificity (PPV-100\%, NPV-100\%) (Table 5). Similarly the cut-off values of serum COMP levels between $652.5 \mathrm{ng} / \mathrm{dl}$ and $801.5 \mathrm{ng} / \mathrm{dl}$ gives a sensitivity $(91.7 \%)$, specificity $(87.4 \%)$ and accuracy $(87 \%)$ to differentiate mild cases from moderate/severe cases. The cut-off values between $801.5 \mathrm{ng} / \mathrm{dl}$ upto $1100.5 \mathrm{ng} / \mathrm{dl}$ to differentiate moderate from mild and severe case with a sensitivity of $78.8 \%$ and specificity of $95 \%$. The cutoff values of $>1100.5 \mathrm{ng} / \mathrm{dl}$ for severe cases gives a sensitivity

Table 1. Demographic Characteristics of Subjects enrolled in the study

\begin{tabular}{|l|l|l|l|l|}
\hline $\mathrm{SN}$ & Characteristic & Control $(\mathrm{n}=50)$ & Cases $(\mathrm{n}=100)$ & Significance of difference \\
\hline 1 & Male:Female & $25: 25: 00$ & $50: 50: 00$ & $\mathrm{x} 2=1 ; \mathrm{p}=1$ \\
\hline 2 & Mean Age \pm SD (years) & $54.68 \pm 9.68$ & $58.93 \pm 9.20$ & $\mathrm{t}=2.621 ; \mathrm{p}=0.010$ \\
\hline 3 & Mean BMI \pm SD $(\mathrm{kg} / \mathrm{m} 2)$ & $23.07 \pm 2.9$ & $24.07 \pm 3.1$ & $\mathrm{t}=1.902 ; \mathrm{p}=0.067$ \\
\hline 4 & $\begin{array}{l}\text { Mean COMP } \pm \text { SD }(\mathrm{ng} / \\
\mathrm{dl})\end{array}$ & $477.02 \pm 60.87$ & $964.18 \pm 152.02$ & $\mathrm{t}=21.774 ; \mathrm{p}<0.001$ \\
\hline
\end{tabular}

Figure 1. Correlation of Serum COMP with age

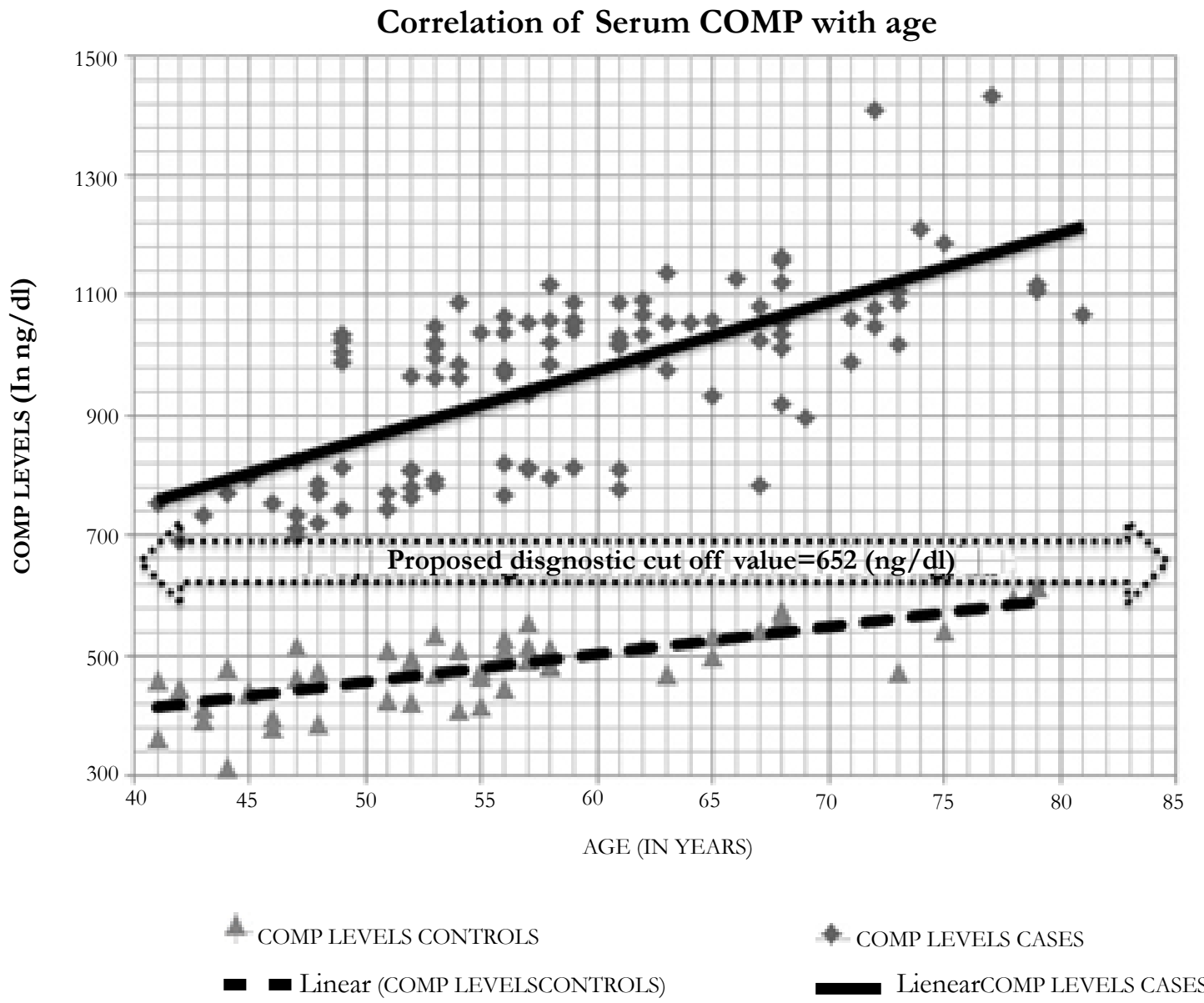

Table 2. Severity of Disease and COMP levels

\begin{tabular}{|l|l|l|l|l|l|l|}
\hline & \multicolumn{5}{|l|}{ COMP Level $(\mathrm{ng} / \mathrm{ml})$} \\
\hline SN & Severity Level & No. of cases & Mean & SD & Min & Max \\
\hline 1 & Mild & 12 & 766.58 & 70.62 & 691 & 967 \\
\hline 2 & Moderate & 80 & 967.61 & 118.32 & 698 & 1127 \\
\hline 3 & Severe & 8 & 1226.25 & 124.29 & 1108 & 1434 \\
\hline F=38.940; $<<0.001$ (ANOVA)
\end{tabular}


Table 3. Receiver Operator Curve Analysis for differentiation between cases and controls

\begin{tabular}{|l|l|l|l|l|}
\hline Area under curve & Std. Error(a) & Asymptotic Sig.(b) & \multicolumn{2}{|l|}{ Asymptotic 95\% Confidence Interval } \\
\cline { 3 - 4 } & & & Lower Bound & Upper Bound \\
\hline 1 & .000 & .000 & 1.000 & 1.000 \\
\hline Efficacy of Regressed cut-off value $\geq 652.5$ & Sensitivity $=100 \%$; Specificity $=100 \%$ \\
\hline a Under the nonparametric assumption, b Null hypothesis: true area $=0.5$
\end{tabular}

Table 4. Receiver-Operator Curve Analysis for Differentiation on the basis of severity among cases

(a) mild cases from moderate and severe

\begin{tabular}{|l|l|l|l|l|}
\hline Area under curve & Std. Error(a) & Asymptotic Sig.(b) & \multicolumn{2}{|l|}{ Asymptotic 95\% Confidence Interval } \\
\cline { 3 - 4 } & & & Lower Bound & Upper Bound \\
\hline 0.934 & 0.03 & $<0.001$ & 0.875 & 0.992 \\
\hline Efficacy of Regressed cut-off value $\leq 801.50$ & Sensitivity $=91.7 \%$ : Specificity $=87.4 \%$ \\
\hline a Under the nonparametric assumption, b Null hypothesis: true area $=0.5$ & \\
\hline
\end{tabular}

\section{(b) severe cases from moderate and mild}

\begin{tabular}{|l|l|l|l|l|}
\hline Area under curve & Std. & Asymptotic Sig.(b) & \multicolumn{2}{|l|}{ Asymptotic 95\% Confidence Interval } \\
\cline { 4 - 4 } & Error(a) & & Lower Bound & Upper Bound \\
\hline 0.994 & 0.007 & $<0.001$ & 0.98 & 1.007 \\
\hline Efficacy of Regressed cut-off value $\geq 1100.50$ & Sensitivity $=100 \% ;$ Specificity $=94.5 \%$ \\
\hline a Under the nonparametric assumption, b Null hypothesis: true area $=0.5$ \\
\hline
\end{tabular}

Table 5. Evaluation of Regressed Cut-off Values

\begin{tabular}{|c|c|c|c|c|c|c|}
\hline SN & Group & Sensitivity & Specificity & PPV & NPV & Accuracy \\
\hline \multicolumn{7}{|c|}{ (a) Control from Cases (COMP <652.5) } \\
\hline 1 & Overall & 100 & 100 & 100 & 100 & 100 \\
\hline 2 & Males & 100 & 100 & 100 & 100 & 100 \\
\hline 3 & Females & 100 & 100 & 100 & 100 & 100 \\
\hline \multicolumn{7}{|c|}{ (b) Mild cases from Moderate/Severe cases $(\geq 652.5$ to 801.50$)$} \\
\hline 1 & Overall & 91.7 & 87.4 & 47.8 & 98.7 & 87 \\
\hline 2 & Males & 100 & 81.8 & 20 & 100 & 82.6 \\
\hline 3 & Females & 90 & 90 & 69.2 & 97.3 & 90 \\
\hline \multicolumn{7}{|c|}{ (c) Moderate cases from Mild/Severe cases (COMP >801.5-<1100.5) } \\
\hline 1 & Overall & 78.8 & 95 & 98.4 & 52.8 & 82 \\
\hline 2 & Males & 77.3 & 100 & 100 & 37.5 & 80 \\
\hline 3 & Females & 80.6 & 92.9 & 96.7 & 65 & 84 \\
\hline \multicolumn{7}{|c|}{ (d) Severe cases from Mild/Moderate cases (COMP $\geq 1100.5$ ) } \\
\hline 1 & Overall & 100 & 94.5 & 61.5 & 100 & 95 \\
\hline 2 & Males & 100 & 95.7 & 66.7 & 100 & 96 \\
\hline 3 & Females & 100 & 93.5 & 57.1 & 100 & 94 \\
\hline
\end{tabular}

of $100 \%$, specificity of $94.5 \%$ with an accuracy of $95 \%$ for differentiation of severe case from moderate case(Table 5).

\section{Discussion}

Osteoarthritis is the most common disease of joints in aging adults and knee joint is most commonly involved besides spine and hip [8]. In clinical scenario the diagnosis is usually based on clinical presentation and radiographs. There are no laboratory tests done to detect or confirm the disease process. Also, the radiological demonstration of typical signs of osteoarthritis of the knee does not correlated with symptoms. Only about $15 \%$ of patients with radiologically demonstrated knee osteoarthritis complain of knee pain[9]. We selected serum Cartilage Oligomeric Matrix Protein (COMP) as a biomarker to correlate its serum levels in mild, moderate and severe grades of knee osteoarthritis with that of normal population. For effective use of this as a diagnostic modality, proper guidelines and cut off levels have to be established to achieve high sensitivity and specificity.

Apart from osteoarthritis, there are few other conditions like 
Rheumatoid arthritis, Systemic lupus erythematosus and joint trauma, where we can find higher serum COMP values. In osteoarthritis itself, there are several factors, which can influence the value of serum COMP. The serum COMP is elevated in osteoarthritis of other joints, especially hip and spine. Hence, we excluded all those patients having any evidence of rheumatoid arthritis, SLE, Psoriasis, any evidence of arthritis in hip or spine.

There are studies, which suggests about transient increase in serum COMP with exercise and decrease to baseline levels after half hour of rest in a seated position [10]. Also diurnal variations in COMP levels have been reported [11]. Hence to avoid these confounding factors, before drawing Blood samples all subjects were made to rest for half an hour in seated position and the timing of drawing of blood samples was in late mid-day (12 noon to $4 \mathrm{pm}$ ).

In our study the serum COMP value steadily increases with age in cases as well as in controls (Fig 1). The correlation of COMP levels with age has also been reported earlier by other previous studies [12],[13]. No gender bias with respect to COMP levels was reported by Clark[14] but Jordan in his study reported higher COMP levels in Caucasian men than Caucasian women which were statistically significant, but no significant difference in COMP values in African American men and women indicating racial influence [13]. Recently strong positive correlation of sex bias with 50\% higher levels in males has been reported [12]. We, in our study found no gender bias with respect to serum COMP levels in either control group or in case group. In control group the mean serum COMP is higher in males $(489.80 \pm 58.20 \mathrm{ng} / \mathrm{dl})$ than females $(464.24 \pm 59.55 \mathrm{ng} / \mathrm{dl})$ but this difference was not significant $(\mathrm{t}=1.50, \mathrm{p}<0.07)$. This may be explained due to more physical activity in males and hence more load on male knee as compared to that of a female. But in case group, the mean serum COMP is marginally higher in females $(967.76 \pm 154.29 \mathrm{ng} / \mathrm{dl})$

Figure 2. Receiver Operator Curve Analysis - Control versus Cases ROC curve

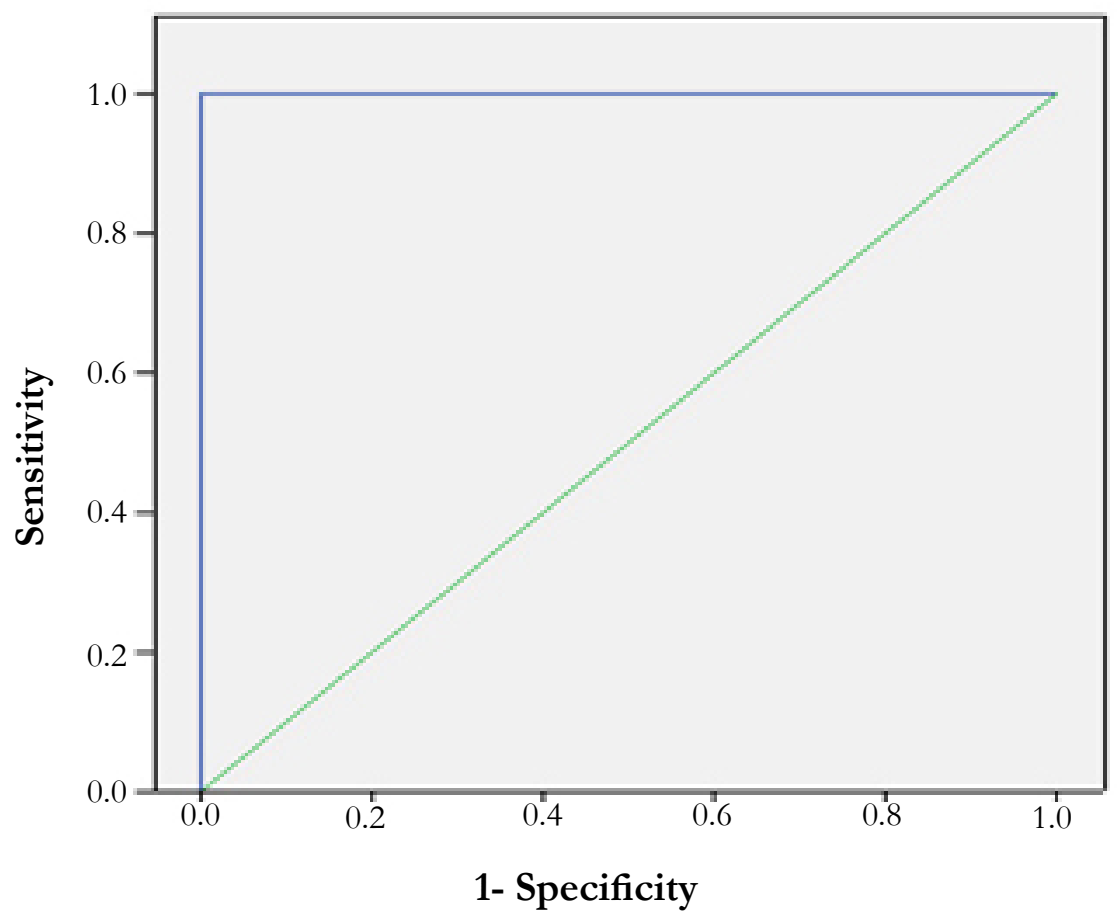

Figure 3: Receiver Operator Curve Analysis - Severity Assessment (a) Mild versus Moderate/Severe ROC curve

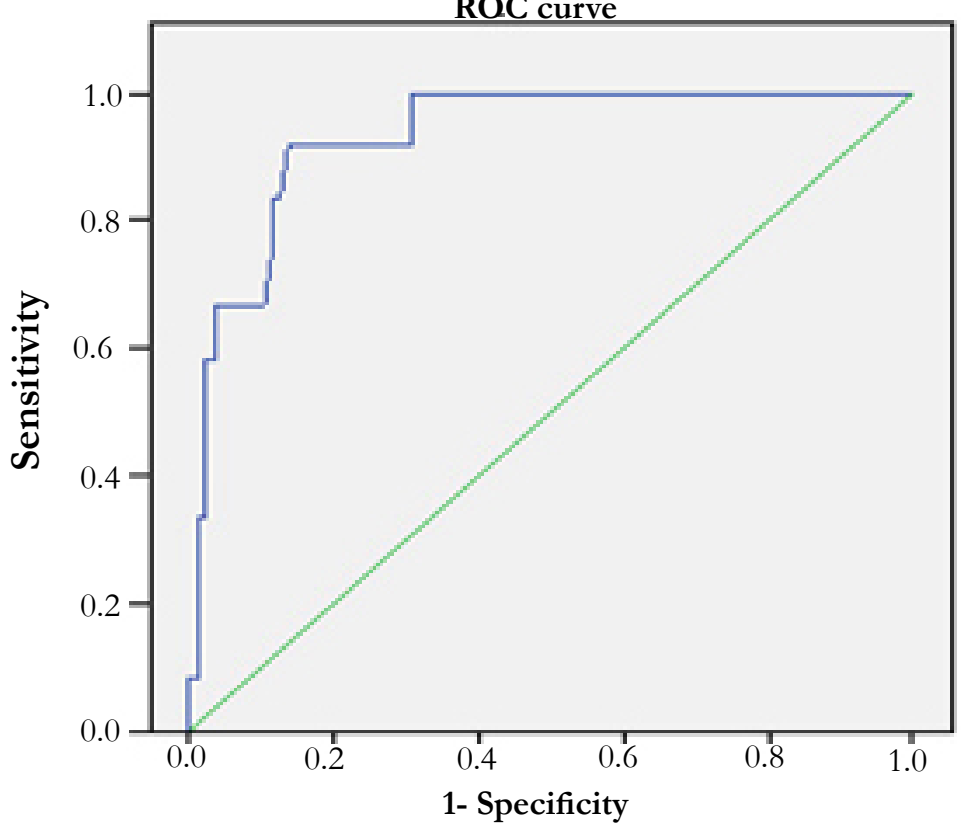


Figure 3. Receiver Operator Curve Analysis - Severity Assessment

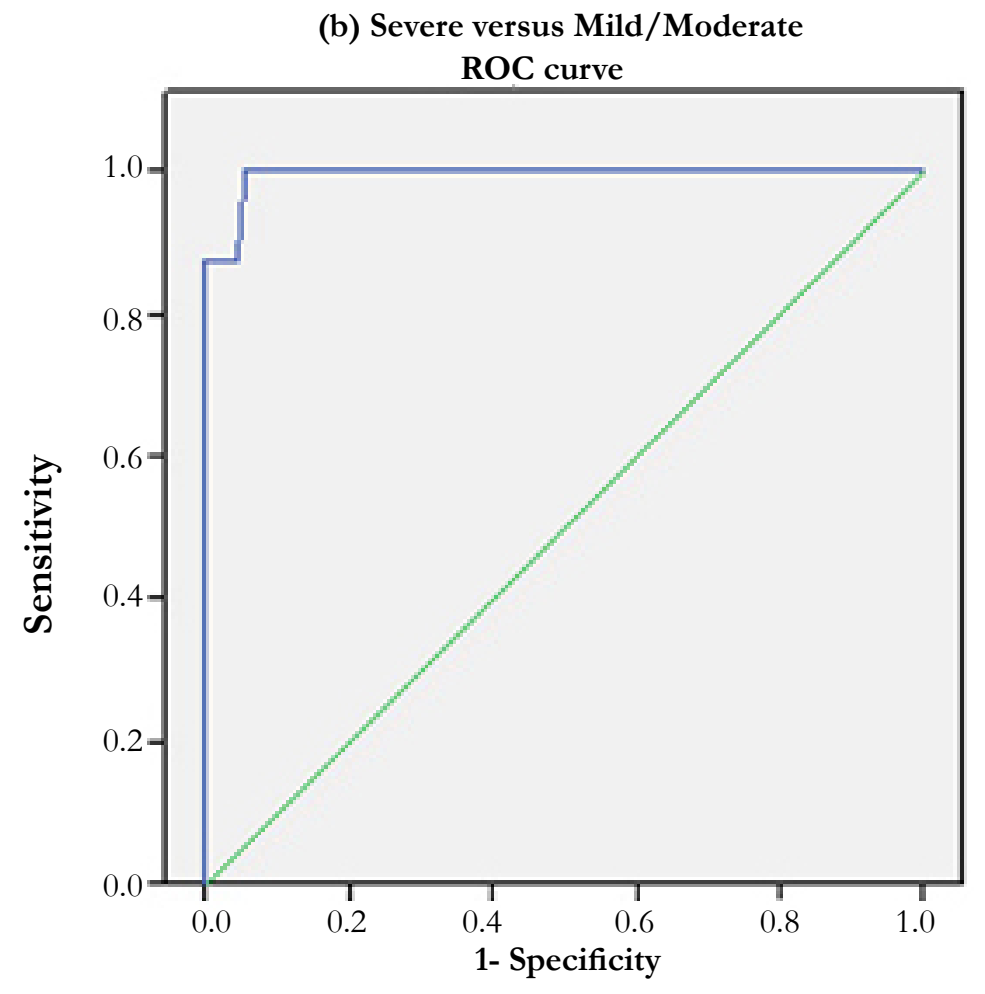

than in males $(960.60 \pm 148.08 \mathrm{ng} / \mathrm{dl})$ but again not statistically significant $(\mathrm{t}=0.23, \mathrm{p}=0.41)$. This maybe because either there is more cartilage damage in females at any K-L Grade, or the disease progression is more rapid in females or women seek medical help later than men.

The ability of serum COMP level in differentiating normal persons with those having osteoarthritis of knee or hip joints has been abundantly reported by many authors and most of them consider it to be a genuine biomarker in detection of knee osteoarthritis[14-19].

In our study we found that the serum COMP value in overall controls ranges between 313 - $614 \mathrm{ng} / \mathrm{dl}$ with a mean value of 477.02 ( \pm 60.87$) \mathrm{ng} / \mathrm{dl}$, whereas the serum COMP value in overall cases range between $691-1434 \mathrm{ng} / \mathrm{dl}$ with a mean value of 964.18 $( \pm 152.02) \mathrm{ng} / \mathrm{dl}$ (Table1). Comparing the Serum COMP values among case and controls in our study we found a statistically significant difference $(\mathrm{t}=21.774 ; \mathrm{p}<0.001)$ (Table 1$)$ which shows the capability of serum COMP levels to adequately differentiate between normal and diseased knees.

Receiver-Operating Characteristic (ROC) curve analysis showed the cut off values of $652.5 \mathrm{ng} / \mathrm{dl}$ with very high sensitivity $(100 \%)$ and specificity (100\%) i.e Serum COMP less than $652.5 \mathrm{ng} /$ $\mathrm{dl}$ should be considered normal and any value above than this should be considered diagnostic for osteoarthritis. This cut off yields 100\% Sensitivity and 100\% specificity to the test (Table 3a, Fig 2).

Several researchers have pointed out the association of level of serum COMP with severity and prognosis of disease [17,19,2123]. However there is one study which doubts about such role of serum COMP in knee osteoarthritis. The authors found no statistically significant associations between any of the knee-related clinical signs and symptoms and COMP [24].

Ahmed M. Awadallah advocated the use of serum COMP level estimation be considered as a screening modality for patients with knee pain and using cut off point of $1097.5 \mathrm{ng} / \mathrm{ml}$ helps to define patients free of $\mathrm{OA}$ and cut off of $1290 \mathrm{ng} / \mathrm{ml}$ to define patients with OA 20 . We did a literature search on internet but did not find anyother study which has tried to correlate the serum COMP level with the severity of the disease with specific cut-off levels. The cut-off levels of serum COMP differ widely in our study with earlier study [20]. The reason of this difference maybe because of different ELISA kit, different sample population (racial variation) or due to some other unknown factor needs to be studied further.

Present study advocates about the association of serum COMP value in assessment of severity of knee osteoarthritis. Thus we can have a cut off for mild, moderate and severe cases for serum COMP. (Table 4,5) (Fig 3). The results of the present study demonstrate a direct association between levels of serum COMP and severity of knee osteoarthritis.

\section{Conclusions}

In the end, following conclusions have been drawn from this study: 1) Serum COMP value is significantly elevated in those suffering from knee osteoarthritis than in normal population, 2) There is an insignificant gender bias in serum COMP values in diseased or normal population, 3) Serum COMP value tend to increase with increasing severity of disease, 4) An acceptable cut off limit can be drawn between normal population, mild moderate and severe grade of knee osteoarthritis for interpretation of results. We suggest keeping all these facts in consideration, a definite guideline for use and interpretation of result for serum COMP in knee osteoarthritis should be designed, so that this can be used as a useful and accurate diagnostic test for diagnosis, assessment of severity and may be also for prognosis and efficacy of on-going treatment in knee osteoarthritis.

\section{Limitations of Study}


We believe that to establish the ability of sCOMP levels to differentiate between normal knee and osteoarthritic knee and the cut-off values suggested by us this study should be replicated bya multicentric study with much larger sample size. Due to lack of financial resources, the sample size taken for study is small for validation of an accurate cut off point.

\section{References}

[1]. Keuttner KE, Golderg VM (1995) Osteoarthritic disorders. AAOS, Rosemont 95-101

[2]. Mangat G, Balakrishnan C, Venkatachalam S, Joshi VR (1995) Pattern of Osteoarthritis in India: a hospital based study. Journal of Indian Rheumatism Association 3(4): 125-8.

[3]. Garnero P, Rousseau JC, Delmas PD (2000) Molecular basis and clinical use of biochemical markers of bone, cartilage and Synovium in joint disease. Arthritis rheum 43: 953-68.

[4]. Garnero P, Geusens P, Landewe R (2003) Biochemical markers of joint tissue turnover in early rheumatoid arthritis. Clin Exp Rheumatol 21 (Suppl. 31): 54-8.

[5]. Rousseau JC, Pierre DD (2007) Biological markers in osteoarthritis. Nat Clin prarheum (396): 346-56

[6]. R. Altman, E. Asch, D. Bloch, G. Bole, D. Borenstein, et al . ( 1986) The American College of Rheumatology criteria for the classification and reporting of osteoarthritis of the knee. Arthritis Rheum 29:1039-49.

[7]. Human Cartilage Oligomeric Matrix Protein ELISA. Product data sheet Cat. No.: RD194080200.

[8]. Felson DT (1988) Epidemiology of knee and hip osteoarthritis. Epidemiol Rev 10:1-28.

[9]. Hannan MT, Felson DT, Pincus T (2000) Analysis of the discordance between radiographic changes and knee pain in osteoarthritis of the knee. J Rheumatol 27: 1513-17.

[10]. Andersson ML, Thorstensson CA, Roos EM, Petersson IF, Heinegård D, et al . (2006) Serum levels of cartilage oligomeric matrix protein (COMP) increase temporarily after physical exercise in patients with knee osteoarthritis. BMC Musculoskelet Disord 7:98.

[11]. Andersson MLE, Petersson IF, Karlsson KE ( 2006) Diurnal variation in serum levels of cartilage oligomeric matrix protein in patients with knee osteoarthritis or rheumatoid arthritis. Ann Rheum Dis 65: 1490-4.

[12]. Verma P, Dalal K (2013) Serum Cartilage Oligomeric protein (COMP) in knee osteoarthritis: a novel diagnostic and prognostic biomarker. J Orthop Res 31(7):999-1006.

[13]. Jordan JM, Luta G, Stabler T, Renner JB, Dragomir AD, et al. (2003) Ethnic and sex differences in serum levels of cartilage oligomeric matrix protein: the Johnston County Osteoarthritis Project. Arthritis Rheum 48 (3):675-81.

[14]. Clark AG, Jordan JM, Vilim V (1999) Serum cartilage oligomeric matrix protein reflects osteoarthritis presence and severity: the Johnston County Osteoarthritis Project. Arthritis Rheum 42:2356-64.

[15]. Neidhart M, Hauser N, Paulsson M, DiCesare P, Michel B, et al .(1997) Small fragments of cartilage oligomeric matrix protein in synovial fluid and serum as markers for cartilage degradation. Br J Rheumato 36:1151-60.

[16]. Conrozier T, Saxne T, Fan CS, Mathieu P, Tron AM, et al. ( 1998 ) Serum concentrations of cartilage oligomeric matrix protein and bone sialoprotein in hip osteoarthritis: a one year prospective study. Ann Rheum Dis 57:52732

[17]. Sharif M, Kirwan JR, Elson CJ, Granell R, Clarke S (2004) Suggestion of nonlinear or phasic progression of knee osteoarthritis based on measurements of serum cartilage oligomeric matrix protein levels over five years. Arthritis Rheum 50:24 79-88.

[18]. Mohammed M.El-Arman, Ghada El-Fayoumi, ElWaleid El-Shal, Ibrahim El-Boghdady (2010) Aggrecan and Cartilage Oligomeric Matrix Protein in Serum and Synovial Fluid of Patients with Knee Osteoarthritis. HSS J 6(2): 171-6.

[19]. J.M. Hoch, C.G. Mattacola, J.M. Medina McKeon, J.S. Howard, C. Lattermann (2011) Serum cartilage oligomeric matrix protein (sCOMP) is elevated in patients with knee osteoarthritis: a systematic review and metaanalysis, Osteoarthritis and Cartilage 19(12):1396-404.

[20]. Awadallah AM, Sabry GH, Khater TM ( 2011) Serum level of cartilage oligomeric matrix protein as a screening modality for osteoarthritis among knee joint pain patients Minerva Biotecnologica 23(2-3):45-52.

[21]. Hanan Darweesh, Doaa Abbass, Randa Kadah, Amal Rashad, Mohamed El Basel, et al.(2010) Serum and synovial cartilage oligomeric matrix protein (COMP) in patients with rheumatoid arthritis and osteoarthritis. Indian Journal of Rheumatology 5(3) : 112-7

[22]. Sharif M, Saxne T, Shepstone L, J. R. Kirwan, C. J. Elson, et al. (1995) Relationship between serum cartilage oligomeric matrix protein levels and disease progression in osteoarthritis of the knee joint. Br J Rheumatol 34:306-10.

[23]. Li H, Wang D, Wu ZQ, Zong JM, Yuan YJ ( 2012) Serum levels of cartilage oligomeric protein in the diagnosis of knee osteoarthritis. Zongguo Gu Shang 25(5):380-3

[24]. Dragomir AD, Kraus VB, Renner JB, Luta G, Clark A, et al. 2002 Serum cartilage oligomeric matrix protein and clinical signs and symptoms of potential pre-radiographic hip and knee pathology. Osteoarthritis Cartilage 10 (9):687-91. 